OnLine Journal of Biological Sciences 9 (1): 29-35, 2009

ISSN 1608-4217

(C) 2009 Science Publications

\title{
Arthropods of Medical Importance in Brazil: Retrospective Epidemiological Information about Accidents Involving these Animals
}

\author{
${ }^{1}$ Danon Clemes Cardoso and ${ }^{2}$ Maykon Passos Cristiano \\ ${ }^{1}$ Deparment of Animal Biology, Graduate Program in Entomology \\ Federal University of Viçosa-UFV \\ ${ }^{2}$ Department of General Biology, Graduate Program in Genetics and \\ Improvement, Federal University of Viçosa-UFV
}

\begin{abstract}
Problem statement: The epidemiological information about arthropods bites/sting in Criciúma region no was reported. The aim of this Research was to draw the epidemiologic profile of accidents with arthropods in Criciúma region. Approach: The information regarding accidents with arthropods from 1994-2006 was prospectively collected from SINAN (System of Injury Notification Information) files of the $21^{\mathrm{a}}$ Municipal Health Secretary of Criciúma region. Was calculated the frequency for each variable studied and incidence coefficient for period of study. Results: Results were recorded 1821 notifications of accidents with arthropods in region studied. The numbers of occurrence increased along of the years studied. The arthropod that most result in accidents was the spider with 1,126 (75.9\%) cases followed by Honeybees and others Arthropods with 149 (10.0\%) cases, Caterpillars including Lonomia genus and others genera (54/3.7\%) and scorpions with the least number of accidents with $6(0.4 \%)$ cases. The incidence of accidents every thousand inhabitants had a significant increase starting in the year of 2000. The majority of accidents occurred in the warmest months, increasing in the spring and summer seasons. Was recorded more than twice of accidents with arthropods in Urban area than in rural areas. The Chi-square test revealed that the frequency of accidents between locations and type of arthropods is different. Likewise, the number the victims and activity type in moment of the bite/sting had been a differ behavior between arthropods type. However, the number of accidents involving victims of male and female gender is equal. Conclusion: Epidemiological studies of this type in the extreme south of Santa Catarina are scarce. Only few studies have reported the patterns of occurrence and incidence of accidents with poisonous animals. These and other studies are of great importance for implementation of measures mitigation programs and education for people, especially for those living in rural areas.
\end{abstract}

Key words: Arthropods, envenomation, spider, honeybee, Criciúma, epidemiology

\section{INTRODUCTION}

The Arthropoda comprise by far the most diverse animal phylum with more than 750,000 species described worldwide ${ }^{[1]}$. The vast majority of species are inoffensive and many are of great economic and social importance. Bees, for example, are important for the maintenance of plant biodiversity, since this insect is the main responsible for pollination of higher plants ${ }^{[2]}$. Naturally, many insects present predatory and defensive behavior based on toxic substances. Since man is part of the ecosystem, it is subject to the same conditions as any natural organism.
Thus, some insects can cause accidents to relevant medical importance, but always linked to defensive behavior of animals and associated with anthropogenic disturbances on the habitat of these animals ${ }^{[3,4]}$. In Brazil, accidents with arthropods of the most importance was recorded with spiders, scorpions, caterpillars, honeybees and wasps ${ }^{[3]}$.

Three genera of spiders have greater medical importance in Brazil: Loxosceles (brown spider), Phoneutria (trap spider) and Latrodectus (widow black). The local pain is the most frequent symptom and may occurred edema, sweating, fasciculation muscular. In more serious cases can result in tachycardia, hypertension and vomiting ${ }^{[3,5]}$.

Corresponding Author: Danon Clemes Cardoso, Programa de Pós-graduação em Entomologia, Departamento de Biologia Animal, UFV, Av. P. H. Rolfs s/n, Centro, Viçosa, MG, 36.570-000, Brazil.

Ph: +55 3186686955 . 
Scorpions stinging is a severe health problem in tropical regions of the world, mainly in countries of the Africa, South Asia and Americas ${ }^{[6-8]}$. In Brazil many cases of accidents with scorpions are recorders for year, representing an average of 50 notifications per year ${ }^{[9]}$. In World, were described approximately 1500 species of scorpions distributed into 16-20 families in different classifications proposed ${ }^{[10]}$. Three species of the Tityus genera are responsible for accidents in Brazil and arise medical importance: Tityus serrulatus, $T$. bahiensis and T. stigumurus ${ }^{[5]}$. The scorpionic venom consist in a blend of proteins and peptides of low molecular weight that inhibit potassium channels as well as alter sodium channel acting on specific sites in the nerve endings of the sympathetic and parasympathetic system and bone releasing epinephrine, norepinephrine and acetylcholine. These neurotransmitters, released as a result of poisoning, are responsible for systemic manifestations ${ }^{[11]}$. Moreover, very severe pain is common in the region of scorpion sting.

The majority of accidents caused by caterpillars occur in individuals exposed to foliage in contact with vegetation. Lonomia is the genus of major medical importance ${ }^{[12]}$. The poison of these Lepidoptera led to allergic reactions, according to the sensitivity of each victim. The principal bee that cause accidents in Brazil is the bees the Apis genus. Accidents with bees, wasps and ants may induce allergic reactions, causing great discomfort or even leading to death because many products of these insects are also capable of causing allergic responses in sensitized people ${ }^{[13]}$. None information about mainly genus of the wasps and ants is recorded, however, knows that the genus of ant Solenopsis, commonly known by the "fire ant" or washfeet, is medicinally important.

Epidemiologic studies were concentrated in Southeast, North e Northeast of Brazil ${ }^{[14,15]}$, and in general they are restricts to epidemiological studies about snake bites ${ }^{[16]}$. In Southern Brazil, epidemiologic studies are scarce, and no study has examined the epidemiologic profile of accidents with arthropods ${ }^{[13,17]}$. Thus, the aim of this study is to draw the epidemiologic profile of accidents with arthropods in Criciúma region, southern Santa Catarina state in Brazil and describe the clinical aspects of these accidents.

\section{MATERIALS AND METHODS}

Criciúma region (Fig. 1) is the socioeconomic province composed by folloing 11 municipalities: Içara, Lauro Müller, Morro da Fumaça, Nova Veneza, Siderópolis, Urussanga, Forquilhinha, Cocal do Sul,

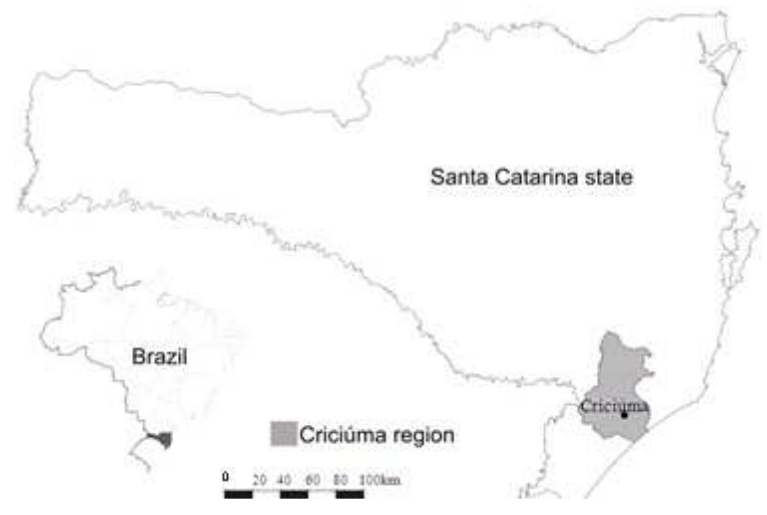

Fig. 1: Studied area of arthropods bites and stings. Map of Brazil with the location of Santa Catarina state and Criciúma region

Treviso, Orleans and Criciúma, the headquarters county. The study area is located southern of Santa Catarina state, Brazil. The region is inserted in the Atlantic Forest biome. The climate is mesotermic with average annual temperature range $22,3^{\circ} \mathrm{C}$ and rainfall distributed throughout the entire year (rainfall ranges from $1200-1660 \mathrm{~mm}$ year $\left.^{-1}\right)^{[18]}$. The economy the municipalities are predominantly rural and occupied a total around 2640000 square $\mathrm{km}$, and the human population is around 340000 inhabitants $^{[19]}$.

Epidemiological information regarding accidents occurring with arthropods from 2000-2006 was prospectively collected from System of Injury Notification Information (SINAN) files of the $21^{\mathrm{a}}$ Municipal Health Secretary. Epidemiological data were recorded including age, gender, geographical location where accident occurred (rural or urban), bite site (location of the sting/bite on the victim's body), activity type and frequency per months. Moreover, were collected clinical information about administration of antivenom, cases evolution and time until health service assistance. Were calculated the frequency for each variable studied and incidence coefficient.

Statistical analysis was performed using the Pearson Chi-squared test to verify similarities between the proportions reported for the groups of arthropods, using $R$ program ${ }^{[20]}$ and values of $\mathrm{p} \leq 0.05$ were considered significant.

\section{RESULTS}

Were recorded 1821 notifications of accidents with arthropods in region of the study and 337 cases of envenomation the arthropod was not indentified. The numbers of occurrence come has increased along of the years. The Table 1 showed the frequency of accidents for year in the period of study and numbers of accidents per animal types. 
OnLine J. Biol. Sci., 9 (1): 29-35, 2009

Table 1: Frequency of accidents for year of the epidemiological data involving different arthropods in Criciúma region, Santa Catarina, Brazil

\begin{tabular}{|c|c|c|c|c|c|c|c|c|c|c|c|c|c|c|c|}
\hline Arthropod type & 1994 & 1995 & 1996 & 1997 & 1998 & 1999 & 2000 & 2001 & 2002 & 2003 & 2004 & 2005 & 2006 & \multicolumn{2}{|c|}{ Total for arthropod type (\%) } \\
\hline Spider & 5 & 18 & 37 & 33 & 29 & 80 & 59 & 121 & 125 & 142 & 147 & 178 & 152 & 1,126 & $(75.9)$ \\
\hline Scorpion & 1 & 0 & 0 & 0 & 0 & 0 & 0 & 1 & 1 & 1 & 0 & 1 & 1 & 6 & $(0.4)$ \\
\hline Honeybee & 1 & 0 & 0 & 0 & 0 & 2 & 1 & 11 & 6 & 14 & 33 & 43 & 38 & 149 & (10.0) \\
\hline Caterpillar Lonomia & 0 & 0 & 0 & 1 & 2 & 1 & 1 & 2 & 1 & 0 & 2 & 2 & 1 & 13 & $(0.9)$ \\
\hline Other caterpillars & 0 & 0 & 0 & 0 & 0 & 0 & 0 & 2 & 2 & 4 & 5 & 17 & 11 & 41 & (2.8) \\
\hline Other arthropods & 0 & 0 & 0 & 1 & 0 & 8 & 6 & 15 & 6 & 18 & 24 & 31 & 40 & 149 & $(10.0)$ \\
\hline Total for year & 7 & 18 & 37 & 35 & 31 & 91 & 67 & 152 & 141 & 179 & 211 & 272 & 243 & $1,484^{\mathrm{a}}$ & $(100.0)$ \\
\hline
\end{tabular}

${ }^{a}$ : The information about the arthropod responsible for the accident was missing in 337(18.5\%) cases

Table 2: Frequency per sex, origin (rural or urban) and activity type of the epidemiological data involving different arthropods in Criciúma region, Santa Catarina, Brazil

\begin{tabular}{|c|c|c|c|c|c|c|c|c|}
\hline Parameters & Spider & Scorpion & Honeybee & Caterpillar Lonomia & Other caterpillars & Other Arthropods & Total & Statistic \\
\hline$\overline{\text { Man }}$ & 562 & 2 & 95 & 10 & 15 & 70 & 754 & $\chi^{2}=18.2491$ \\
\hline Women & 564 & 4 & 55 & 3 & 26 & 79 & 731 & $\mathrm{p}=0.00265^{*}$ \\
\hline Total . . & 1126 & 6. & 150. & 13. & 41. & 149. & $1,485^{\mathrm{a}}$ & \\
\hline Urban & 794 & 2 & 105 & 9 & 32 & 107 & 1,049 & $\chi^{2}=1.8925$ \\
\hline Rural & 319 & 2 & 44 & 4 & 9 & 42 & 420 & $\mathrm{p}=0.8638$ \\
\hline Total & 1,113 & .4 & 149. & 13 & 41 & 149. & $1,469^{\mathrm{b}}$ & \\
\hline Working & 537 & 4 & 72 & 7 & 10 & 65 & 695 & $\chi^{2}=9.5469$ \\
\hline Leisure & 549 & 2 & 73 & 6 & 28 & 79 & 737 & $\mathrm{p}=0.08914$ \\
\hline Total & 1,086 & 6 & 145 & 13 & 38 & 144 & $1,432^{\mathrm{c}}$ & \\
\hline
\end{tabular}

${ }^{a}$ : In 336 cases this information was unknown; ${ }^{b}: 352$ cases with insufficient information in SINAN files; ${ }^{c}$ : In 389 cases this information was unknown; *: Significant at $0.01 \%$

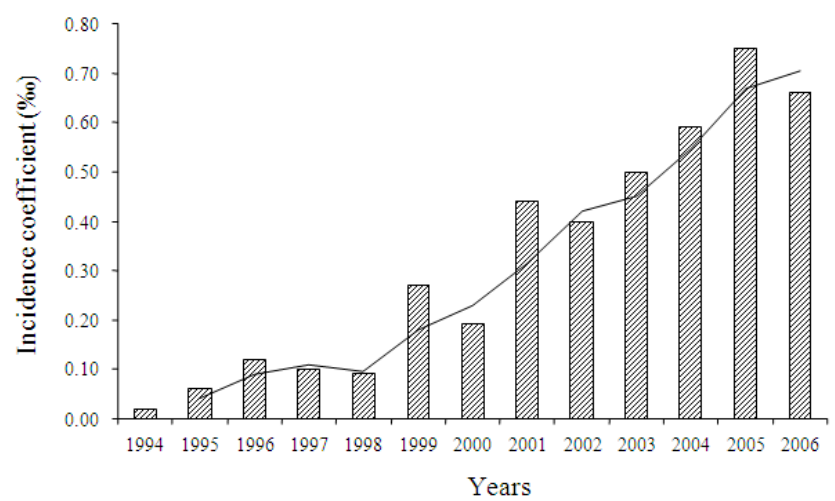

Fig. 2: Incidence of accidents involving different arthropods in Criciúma region, Santa Catarina, Brazil

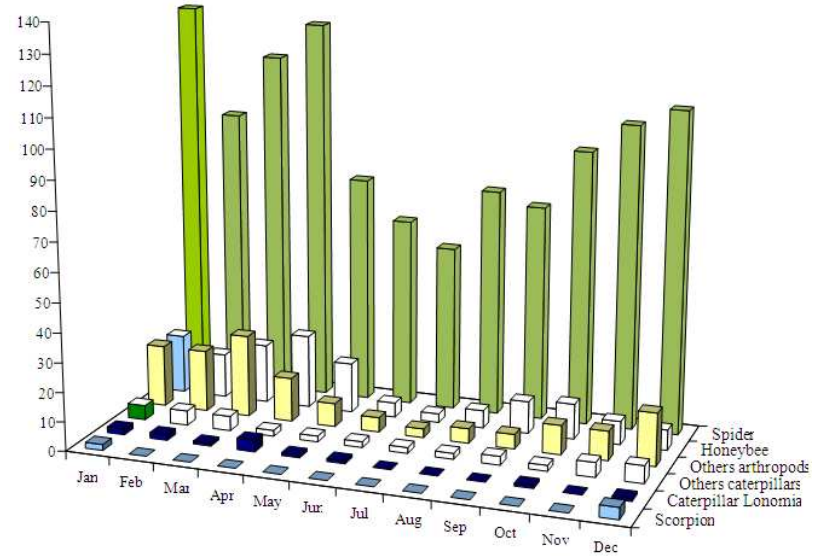

Fig. 3: Frequency of accidents per months and arthropod type in Criciúma region, Santa Catarina, Brazil. In 337 cases none information were recorded in SINAN files 
OnLine J. Biol. Sci., 9 (1): 29-35, 2009

Table 3: Frequency of accidents per bite/sting site and age of the epidemiological data involving different arthropods in Criciúma region, Santa Catarina, Brazil

\begin{tabular}{|c|c|c|c|c|c|c|c|c|}
\hline \multirow{2}{*}{$\begin{array}{l}\text { Parameters } \\
\text { Local bite/sting }\end{array}$} & \multirow[t]{2}{*}{ Spider } & \multirow[t]{2}{*}{ Scorpion } & \multirow[t]{2}{*}{ Honeybee } & \multirow[t]{2}{*}{ Caterpillar Lonomia } & \multirow[t]{2}{*}{ Other caterpillars } & \multirow[t]{2}{*}{ Other arthropods } & \multicolumn{2}{|c|}{ Total $(\%)$} \\
\hline & & & & & & & & \\
\hline Head & 57 & 0 & 45 & 1 & 2 & 37 & 142 & $(10.0)$ \\
\hline Arm & 93 & 0 & 12 & 1 & 8 & 21 & 135 & $(9.5)$ \\
\hline Forearm & 64 & 1 & 7 & 3 & 8 & 12 & 95 & (6.7) \\
\hline Hand & 185 & 1 & 23 & 1 & 6 & 17 & 233 & (16.4) \\
\hline Fingers hand & 166 & 1 & 5 & 1 & 7 & 9 & 189 & (13.3) \\
\hline Trunk & 72 & 0 & 17 & 2 & 2 & 14 & 107 & $(7.5)$ \\
\hline Thigh & 66 & 0 & 3 & 0 & 1 & 5 & 75 & (5.3) \\
\hline Leg & 129 & 2 & 4 & 1 & 3 & 6 & 145 & $(10.2)$ \\
\hline Feet & 155 & 1 & 6 & 1 & 2 & 11 & 176 & (12.4) \\
\hline Fingers feet & 89 & 0 & 20 & 1 & 1 & 13 & 124 & $(8.7)$ \\
\hline Total & 1,076 & 6 & 142 & 12 & 40 & 145 & $1,421^{\mathrm{a}}$ & (100.0) \\
\hline \multicolumn{9}{|l|}{ Age (years): } \\
\hline$<1$ Year old & 14 & 1 & 1 & 1 & 1 & 2 & 20 & (1.4) \\
\hline $1-4$ & 65 & 0 & 5 & 2 & 0 & 11 & 83 & (5.6) \\
\hline $5-9$ & 52 & 0 & 5 & 0 & 5 & 21 & 83 & (5.6) \\
\hline $10-14$ & 72 & 0 & 7 & 0 & 8 & 20 & 107 & (7.2) \\
\hline $15-19$ & 107 & 1 & 26 & 2 & 3 & 7 & 146 & (9.8) \\
\hline $20-34$ & 320 & 2 & 53 & 3 & 6 & 38 & 422 & (28.4) \\
\hline $35-49$ & 265 & 1 & 36 & 2 & 8 & 28 & 340 & (22.8) \\
\hline $50-64$ & 152 & 1 & 9 & 3 & 8 & 16 & 189 & (12.7) \\
\hline $65-79$ & 74 & 0 & 6 & 0 & 2 & 6 & 88 & $(5.9)$ \\
\hline 80 or more & 9 & 0 & 2 & 0 & 0 & 0 & 11 & $(0.7)$ \\
\hline Total & 1,130 & 6 & 150 & 13 & 41 & 149 & $1,489^{\mathrm{b}}$ & $(100.0)$ \\
\hline
\end{tabular}

${ }^{\mathrm{a}}$ : In 400 cases this information was unknown, ${ }^{\mathrm{b}}: 332$ cases with insufficient information in SINAN files

Table 4: Frequency of accidents for group admission and evolution case for arthropod type

\begin{tabular}{|c|c|c|c|c|c|c|c|c|}
\hline Parameters & Spider & Scorpion & Honeybee & Caterpillar Lonomia & Other caterpillars & Other arthropods & & Total $(\%)$ \\
\hline \multicolumn{9}{|l|}{ Group admission } \\
\hline Mild & 817 & 4 & 110 & 12 & 36 & 114 & 1,093 & (77.8) \\
\hline Moderate & 232 & 2 & 30 & 1 & 4 & 25 & 294 & $(20.9)$ \\
\hline Grave & 17 & 0 & 1 & 0 & 0 & 0 & 18 & $(1.3)$ \\
\hline Total & 1,066 & 6 & 141 & 13 & 40 & 139 & $1,405^{\mathrm{a}}$ & $(100.0)$ \\
\hline \multicolumn{9}{|l|}{$\overline{\text { Evolution }}$} \\
\hline Cure & 1,041 & 6 & 139 & 13 & 38 & 140 & 1,377 & (98.4) \\
\hline Cure with sequelae & 15 & 0 & 2 & 0 & 0 & 4 & 21 & $(1.5)$ \\
\hline Death & 0 & 0 & 1 & 0 & 0 & 0 & 1 & $(0.1)$ \\
\hline Total & 1,056 & 6 & 142 & 13 & 38 & 144 & $1,399^{b}$ & $(100.0)$ \\
\hline
\end{tabular}

${ }^{\mathrm{a}}:$ In 416 cases this information was unknown, ${ }^{\mathrm{b}}: 422$ cases with insufficient information in SINAN files

The arthropod that most result in accidents was the spider with $1,126(75.9 \%)$ cases, followed by Honeybees and Others Arthropods with 149 (10.0\%) cases, Caterpillars including Lonomia genus and others genera $(54 / 3.7 \%)$ and Scorpions with de least number of accidents with $6(0.4 \%)$ cases.

The incidence coefficient for arthropod accidents from 1994-2006 is showed in Fig. 2. The incidence of accidents every thousand inhabitants had a significant increase starting in 2000. The frequencies of accidents per months are shown in Fig. 3. The majority of accidents occur in the warmest months, increase in the spring and summer seasons and turning to decrease in the last autumn and in months of winter. These pattern was extensively treated in others researchers ${ }^{[13,16,17]}$.

Were recorded more than twice of accidents with arthropods in Urban area, 71.4\% $(\mathrm{n}=1,049)$ whereas only $28.6 \%(n=420)$ were from rural areas (Table 2). The Chi-square test revealed that the frequency of accidents between locations and type of arthropods is different, since the statistic null hypothesis was rejected $\left(\chi^{2}=1.8925, p=0.86\right)$. Likewise, the number the victims and activity type in moment of the bite/sting have been a differ behavior between arthropods type, once statistic null hypothesis was rejected $\left(\chi^{2}=9.5469\right.$, $\mathrm{p}=0.089$ ). However, the number of accidents involving men and women was statistically equal (Table 2). In these case the statistic null hypothesis was accepted $\left(\chi^{2}\right.$ $=18.2491, \mathrm{p}=0.002$ ).

The anatomic region that suffered more stings are hands $(16.4 \%, \mathrm{n}=233$, Table 3$)$, followed by the fingers hand, feet, legs, head, arm, fingers feet, trunk, forearm and thigh $(10.0,9.5,6.7,13.3,7.5,5.3,10.2$, 12.4 and $8.7 \%$, respectively, Table 3). Moreover, a 
higher accident frequency of $28.4 \%(\mathrm{n}=422$, Table 3$)$ was observed in the age group 20-34 years old, followed by $35-49$ age group $(22.8 \%)$.

In $1,093(77.8 \%)$ patients had mild envenoming, whereas $294(20.9 \%)$ had moderate and $18(1.3 \%)$ grave envenoming (Table 4). None information about arthropod species involved in moderate or grave cases may be due to lack of information in the records. In addition, only one death was recorded in SINAN files and $98.4 \%$ of the patients recovery, however, 21 (1.5\%) of the patients recovery with sequelae.

\section{DISCUSSION}

We recorded a total of 1821 cases of accidents with arthropods in the studied region, however in 337 cases no information about animal, age, locality, gender, year, were available. This result shows that the SINAN files are not accurately filled. This issue is very mentioned in literature and two mainly difficulties are highlights: (i) The patient not carry the animal for the medical center toward possible the identification, or, (ii) The health agents are haven't able for this ${ }^{[13,17]}$. Another issue that needs to be discussed is the lack of commitment to the filling of SINAN form by the health agent ${ }^{[21]}$. The system was initially created to manage the demand for serum for the treatment of these accidents with poising animals, which was in crisis in the decade of $80^{\text {th }}$ in Brazil ${ }^{[22]}$.

The registers of arthropods bites and stings increased from 1994 to 2006 (Fig. 3). The increase in the number of cases may be the result of the increase of urban population. This framework is supported, since the number of reported cases is much higher in urban centers (Table 2). Another support to this hypothesis is incidence to 1000 habitants on that accelerated growth in the last six years (Fig. 2). The urbanization and the expressible growth of the cities may be one of the factors for the increase of arthropods stinging. The extension and perturbation of their natural habitat, the animals begin to inhabit other environments in the city[23].

The spiders and scorpion, for example, are arthropods that present nocturnal habits and live into or near of our houses. The majority of encounters between theses arthropods and humans may happen here. This justifies the $794(71.3 \%)$ register of the spider bites in urban area against 319 (28.7\%) register for rural area. In these localities there is a more number of forest remainder and more environments whereas these animals can be live. Then in Urban area the arthropods living surrounding or into de residencies, in beds, shoes and clothing. When accidentally squeeze or forebodingly threat the arthropod sting/bite the victims ${ }^{[24]}$.

The incidence of accidents with arthropods in men and women was statistically equal (Table 2). We believe that the potential victim is a result of chance. That is, the encounter with the Arthropod concerned. The anatomic region that suffered the most stings/bites appears to be far more dependent of the chance than on the preference of the stinging arthropod. The accidents with arthropods can usually be prevented by simple, personal and domestic measures such as, checking shoes, clothing and beds, sealing holes and cracks in walls of the houses reducing hiding places[17,24]. The predominant age group of the victims was 20-34 years old followed by 35-49 age group, which consist with data from the literature[25,26]. This parcel of population correspond a more active group as economically as in leisure times.

In worldwide few species can be cause fatal accidents in humans. Nevertheless, the majority of accidents received in medical centers in Carboniferous region are classified as mild envenoming, however, the considerable number of cases were recorded as moderate $(415,21.53 \%)$. This is not observed in accidents with spiders for the same region (data unpublished) and honeybees and caterpillars ${ }^{[13]}$. This fact may be due the higher toxicity of scorpion venom in humans ${ }^{[27]}$. Likewise, the majority the victims not receive antivenom therapy, in spite that only patients with systemic envenomation (some moderate cases and all severe cases) require antivenom therapy ${ }^{[24]}$.

The observed low frequency of fatal victims (one dead were recorded) and lower frequency of the victims recovery with sequelae suggests that the public health system is efficient and also indicates that the system is fast and well developed. On the other hand, the possibility that there are just few allergic persons among this specific population and the relative low number of victims between 0-14 years and older than 65 years old were responsible for this better scenario. The symptoms of envenomation are more pronounced in infants, young children, and the elderly. Moreover, the severity of envenoming can be varies with the victims size and species of arthropod or still due the amount of venom inoculate for stinging animal in the victims.

\section{CONCLUSION}

Epidemiological studies of this type in the southern of Santa Catarina are scarce. Only few studies have reported the patterns of occurrence and incidence of 
accidents with poisonous animals ${ }^{[13,17,28]}$. The present study suggests that training programs are necessary for health workers in order to improve the data in the forms of SINAN system. Another important point about SINAN forms is the needs to separate the category "other arthropods" into two categories: Wasps and Ants, since the existing category does not allow the assessment of accidents involving these animals. These and other studies are of great importance for implementation of measures mitigation programs and education for people, especially for families living in rural areas.

\section{REFERENCES}

1. Wilson, E.O., 1991. The Current State of Biological Diversity. In: Learning to Listen to the Land, Willers, W.B. (Ed.). Island Press, ISBN: 1559631201, pp: 282.

2. Michener CD (2000) The bees of the world. The Johns Hopkins press, Baltimore and Lodon. ISBN10: 0801861330.

3. Freitas G.C.C., A.E. Oliveira Jr., J.E.B. Farias and S.D. Vasconcelos, 2006. Accidents caused by spiders, insects and centipede registered service center in the toxicity of pernambuco (1993-2003). Rev. Patol. Trop., 35: 148-156. http://www.iptsp.ufg.br/download/2006_36(2)148_ 156.pdf

4. Barroso, E., A.S.V. Hidaka, A.X. Santos, J.M. França, A.M.B. Sousa, J.R. Valente, A.F.A. Magalhães and P.P.O. Pardal, 2001. Centipede accidents notified by Toxicological Information Center of Belém, over a two-year period. Rev. Soc. Bras. Med. Trop., 34: 527-530. DOI: 10.1590/S003786822001000600005

5. Brasil, 2005. Contingency Plan of Health Surveillance Facing Floods. Ministry of Health, Department of Health Surveillance (SVS / MS), Brasília.

http://portal.saude.gov.br/portal/arquivos/pdf/plano _de_contigencia_final_jan05.pdf

6. Soulaymani-Bencheikh, R., A. Soulaymani, I. Semlali, O.K. Tamim, F. Zemrour, R. Eloufir and A. Mokhtari, 2005. Scorpion stings and envenomation in the population of Khouribga (Morocco). Bull Soc. Pathol. Exot., 98: 36-40. http://www.pathexo.fr/documents/articlesbull/2005/2005n1/T98-1-2654-5p.pdf

7. Jahan, S., A.S.A. Mohammed and S. Abdul Rahim Hamed, 2007. Scorpion stings in Qassim, Saudi Arabia-a 5-year surveillance report. Toxicon, 50: 302-305. DOI: 10.1016/j.toxicon.2007.03.013
8. Ozkan, O., R. Uzun, S. Adiguzel, Y. Cesaretli and M. Ertek, 2008. Evaluation of scorpion sting incidence in turkey. J. Venom. Anim. Toxins incl. Trop. Dis., 14: 128-140. DOI: 10.1590/S167891992008000100010

9. São Paulo., 2007. Superintendency for the Control of Endemic, State Department of Health of São Paulo. Integrated management to prevent the proliferation of vectors of dengue and leishmaniasis and scorpions. Rev Saude Publica., 41: 317-320. www.scielo.br/pdf/rsp/v41n2/24sau.pdf

10. Prendini, L. and W.C. Wheeler, 2005. Scorpion higher phylogeny and classification, taxonomic anarchy, and standards for peer review in online publishing. Cladistics, 21: 446-494. DOI: 10.1111/j.1096-0031.2005.00073.x

11. Otero, R., E. Navío, F.A. Céspedes, M.J. Núñez, L. Lozano and E.R. Moscoso et al., 2004. Scorpion envenoming in two regions of Colombia: Clinical, epidemiological and therapeutic aspects. Trans. R. Soc. Trop. Med. Hyg., 98: 742-50. DOI: 10.1016/j.trstmh.2003.12.018

12. Specht, A., E. Corseuil and A.C. Formentini, 2006. Lepidoptera of medical importance occur in "Rio Grande do Sul". Biosciences, 14: 53-60. http://revistaseletronicas.pucrs.br/ojs/index.php/fab io/article/viewFile/199/181

13. Cristiano, M.P. and D.C. Cardoso, 2008. Honeybees and caterpillars: Epidemiology of accidents involving these animals in the Criciuma region, southern Santa Catarina state, Brazil. J. Venom. Anim. Toxins incl. Trop. Dis., 14: 719-724. DOI: 10.1590/S1678-91992008000400013

14. Azevedo-Marques, M.M., 1994. Diagnosis and pipelines in accidents by scorpions and bees. Rev. Soc. Bras. Med. Trop., 27: (supl 4) 683-688. DOI: $10.1590 /$ S0037-86822000000300001

15. Carvalho, L.S., M.P. Santos and S.C. Dias, 2007. Scorpionism in the rural zone of Teresina, State of Piauí: Relate of envenomation cases. Rev. Soc. Bras. Med. Trop., 40: 491. DOI: 10.1590/S003786822007000400027

16. Silva, C.J., M.T. Jorge and L.A. Ribeiro, 2003. Epidemiology of snakebite in a central region of Brazil. Toxicon, 41: 251-255. DOI:10.1016/S00410101(02)00287-8

17. Cardoso, D.C., M.P. Cristiano, M.S. Raymundo, S. Costa and J.J. Zocche, 2007. Epidemiology and injuries (1994-2005) resulting from poisonous animals in southern Santa Catarina State, Brazil. J. Public Health, 15: 467-472. DOI: 10.1007/s10389007-0095-3 
18. Dufloth J.H., N. Cortina, M. Veiga and L.C. Mior, 2005. Basic studies of regional Santa Catarina. Florianópolis. EPAGRI-Enterprise for Agricultural Research and Rural Extension of Santa Catarina SA, Florianópolis, SC. [CD-ROM].

19. IBGE-Instituto Brasileiro de Geografia e Estatística. Cidades@: IBGE, 2007. Accessed 5 december 2008.

http://www.ibge.gov.br/cidadesat/topwindow.htm

20. R Development Core Team, 2008. R: A language and environment for statistical computing. R Foundation for Statistical Computing, Vienna, Austria. ISBN: 3-900051-07-0.

21. Judith Tiomny Fiszon, J.T. and R. Bochner, 2008 Underreporting of accidents with venomous animals registered by SINAN in the State of Rio de Janeiro from 2001 to 2005. Rev. Bras. Epidemiol., 11: $114-127$ DOI: $10.1590 / \mathrm{S} 1415-$ 790X2008000100011

22. Bochner, R. and C.J. Struchiner, 2002. Recording of venomous bites and stings by national information systems in Brazil. Cad Saúde Pública, 18: 735-746. DOI: $10.1590 /$ S0102$311 \times 2002000300022$.

23. Junghanss, T. and M. Bodio, 2006. Medically important venomous animals: Biology, prevention, first aid, and clinical management. Clin. Infect. Dis., 15: 1309-1317. DOI: 10.1086/508279
24. Carvalho, M.A. and F. Nogueira, 1998. Snakes from the urban area of Cuiabá, Mato Grosso: Ecological aspects and associated snakebites Cad. Saúde Pública, 14: 753-763. DOI: 10.1590/S0102311X1998000400017

25. Ozkan, O. and I. Kat, 2005. Mesobuthus eupeus scorpionism in Sanliurfa region of Turkey. J. Venom. Anim. Toxins incl. Trop. Dis., 11: 479-491. DOI: $10.1590 /$ S1678-91992005000400008

26. Srivastava, A., S.S. Peshin, T. Kaleekal and S.K. Gupta, 2005. An epidemiological study of poisoning cases reported to the national poisons information centre, All India institute of medical sciences, New Delhi. Hum. Exp. Toxicol., 24: 279-285. DOI: 10.1191/0960327105ht527oa

27. Elston, D.M., 2005. Life-threatening stings, bites, infestations and parasitic diseases. Clin. Dermatol., 23: 164-170.

DOI: 10.1016/j.clindermatol.2004.06.010

28. Cristiano, M.P., D.C. Cardoso and M.S. Raymundo, 2009. Contextual analysis and epidemiology of spider bite in southern Santa Catarina state, Brazil. Trans. R. Soc. Med. Hyg. 109: 1-6 DOI: 10.1016/j.trstmh.2009.03.015 